Jurnal Pemberdayaan: Publikasi Hasil Pengabdian kepada Masyarakat

Vol. 2, No. 1, April 2018, Hal. 171-176

ISSN: 2088 4559; e-ISSN: XXXX-XXXX

DOI:

\title{
UPAYA PENINGKATAN PENGETAHUAN TENTANG HIPERTENSI MELALUI METODE PENYULUHAN
}

\author{
Liena Sofiana ${ }^{1}$, Yudha Puratmadja, Baiq Sandi Kartika S, Abdul Haris R Pangulu, Ika \\ Handayani Putri ${ }^{2}$ \\ Universitas Ahmad Dahlan, Yogyakarta \\ ${ }^{2}$ Mahasiswa Universitas Ahmad Dahlan Yogyakarta \\ Email: liena.sofiana@ikm.uad.ac.id
}

\begin{abstract}
ABSTRAK
Hipertensi masih merupakan masalah besar di Indonesia dengan prevalensi sebesar 25,8\%. Berdasarkan data Dinas Kesehatan Kabupaten Kulon Progo pada tahun 2014 hipertensi termasuk dalam 10 besar penyakit dengan jumlah kasus sebanyak 48.929 kasus. Peningkatan kasus ini disebabkan oleh beberapa faktor yaitu kurangnya pengetahuan, sikap yang dimiliki masyarakat mengenai hipertensi sehingga masyarakat memiliki perilaku yang rendah dalam melakukan pencegahan hipertensi. Pendidikan kesehatan dengan menggunakan metode penyuluhan merupakan cara yang dapat dilakukan untuk meningkatkan pengetahuan. Tujuan dari artikel ini adalah untuk mengetahui gambaran pengetahuan mengenai hipertensi melalui penyuluhan. Metode yang digunakan adalah dengan penyuluhan kesehatan interaktif pada ibu-ibu di dusun Bantar Kulon dan Bantar Wetan secara langsung dengan menggunakan power point sebagai penyajian materi penyuluhan. Hasil yang diperoleh adalah kegiatan penyuluhan kesehatan berjalan dengan baik dan lancar, peserta aktif bertanya dan mengikuti penyuluhan dari awal sampai selesai.
\end{abstract}

Kata kunci: Penyuluhan kesehatan, hipertensi, pengetahuan

\begin{abstract}
Hypertension is still a big problem in Indonesia with a prevalence of 25.8\%. Based on data from the Kulon Progo District Health Office in 2014 hypertension was included in the top 10 diseases with a total of 48,929 cases. This increase in cases is caused by several factors, namely lack of knowledge, attitudes held by the community regarding hypertension so that people have low behavior in preventing hypertension. Health education using extension methods is a way that can be done to increase knowledge. The purpose of this article is to find out the description of knowledge about hypertension through counseling. The method used was interactional health counseling for mothers in Bantar Kulon and Bantar Wetan hamlets directly by using power point as presentation of counseling material. The results obtained were health education activities went well and smoothly, active participants asked questions and attended counseling from the beginning to completion.
\end{abstract}

Keywords: Health Education, hypertension, knowledge 


\section{PENDAHULUAN}

Hipertensi adalah peningkatan tekanan darah sistolik lebih dari $140 \mathrm{mmHg}$ dan tekanan darah diastolik lebih dari $90 \mathrm{mmHg}$ pada dua kali pengukuran dengan selang waktu lima menit dalam keadaan cukup istirahat/tenang. Peningkatan tekanan darah dengan jangka waktu yang lama dapat menimbulkan kerusakan pada ginjal, jantung dan otak apabila tidak dilakukan pengobatan secara dini (Kementerian Kesehatan Republik Indonesia, 2017). Prevalensi hipertensi nasional berdasarkan Riskesdas 2013 sebesar 25,8\% dengan orang yang mengalami hipertensi hanya $1 / 3$ yang terdiagnosis sedangkan $2 / 3$ tidak terdiagnosis dan $0,7 \%$ orang yang terdiagnosis tekanan darah tinggi dengan memiliki kebiasaan meminum obat hipertensi. Hal ini menunjukkan bahwa sebagian besar penderita hipertensi tidak menyadari menderita hipertensi ( Kementerian Kesehatan Republik Indonesia, 2017).

Berdasarkan data Dinas Kesehatan Kabupaten Kulon Progo pada tahun 2014 hipertensi termasuk dalam 10 besar penyakit dengan jumlah kasus sebanyak 48.929 kasus (Dinas Kesehatan Kabupaten Kulon Progo, 2015). Faktor risiko hipertensi adalah umur, jenis kelamin, riwayat keluarga, genetik, kebiasaan merokok, konsumsi garam, konsumsi lemak jenuh, kebiasaan minum-minuman beralkohol, obesitas, kurang aktivitas fisik, stress dan penggunaan estrogen (Kementerian Kesehatan Republik Indonesia, 2017). Selain faktor tersebut ada beberapa faktor yang mempengaruhi seseorang terkena hipertensi yaitu masih kurangnya pengetahuan dan sikap mengenai hipertensi. Hasil penelitian membuktikan ada hubungan antara pengetahuan tentang hipertensi dengan pengendalian tekanan darah, responden dengan tingkat pengetahuan baik tentang hipertensi umumnya tekanan darahnya terkendali, sedangkan responden yang mempunyai tingkat pengetahuan tidak baik mengenai hipertensi umumnya tekanan darahnya tidak terkendali (Wulansari, Ichsan and Usdiana, 2013).

Pengetahuan pasien hipertensi yang sudah baik itu diperoleh dari media elektronik seperti televisi, radio, internet, membaca majalah atau lewat promosi kesehatan dari petugas kesehatan dan juga dari teman-teman terdekat yang mengetahui tentang penyakit hipertensi (Dirhan, 2012). Adanya peningkatan pengetahuan tentang hipertensi setelah pemberian pendidikan dengan skor rerata yaitu 4,46 (sebelum) dan 13,97 (setelah), yang artinya pemberian pendidikan kesehatan dapat meningkatkan pengetahuan mengenai hipertensi pada lansia (Fitria and Candrasari, 2010).

Pengetahuan bisa didapatkan melalui pendidikan kesehatan. Pendidikan kesehatan tentang perawatan hipertensi pada anggota keluarga dapat memberikan informasi yang 
dibutuhkan keluarga yang dapat meningkatkan pengetahuan keluarga sehingga keluarga dapat menentukan sikap yang lebih baik dalam perawatan hipertensi anggota keluarga (Mardhiah, Abdullah and Hermansyah, 2013). Penyuluhan kesehatan berpengaruh terhadap peningkatan pengetahuan perilaku klien hipertensi, akan meningkatkan pola hidup sehingga dapat mengontrol tekanan darah dengan baik (Purwati, Bidjuni and Babakal, 2014). Berdasarkan hal tersebut maka sangat diperlukan adanya kegiatan penyuluhan mengenai hipertensi di Dusun Banter Wetan dan Bantar Kulon Banguncipto Kulon Progo Yogyakarta.

\section{METODE}

Bahan yang digunakan dalam upaya promosi kesehatan pencegahan hipertensi adalah materi presentasi tentang hipertensi dan faktor risikonya terdiri dari file power point tentang hipertensi, LCD dan layar proyektor. Metode yang digunakan dalam promosi kesehatan ini adalah metode penyuluhan dan pemeriksaan tekanan darah dan dilanjutkan dengan tanya jawab serta diskusi.

\section{HASIL, PEMBAHASAN, DAN DAMPAK}

Kegiatan pengabdian kepada masyarakat ini dilakukan di dusun Bantar Kulon dan Bantar Wetan, Banguncipto Sentolo Kulon Progo pada tanggal 2 Februari 2018 dan 9 Februari untuk pendampingannya. Peserta kegiatan adalah ibu-ibu dasawisma setempat. Pelaksanaan kegiatan berupa pemberian materi mengenai hipertensi melalui media promosi kesehatan yaitu penyuluhan dilanjutkan dengan tanya jawab dan diskusi serta dilakukan pemeriksaan kesehatan yaitu tekanan darah. Gambar 1 dan 2 adalah foto-foto kegiatan selama pelaksanaan pengabdian.

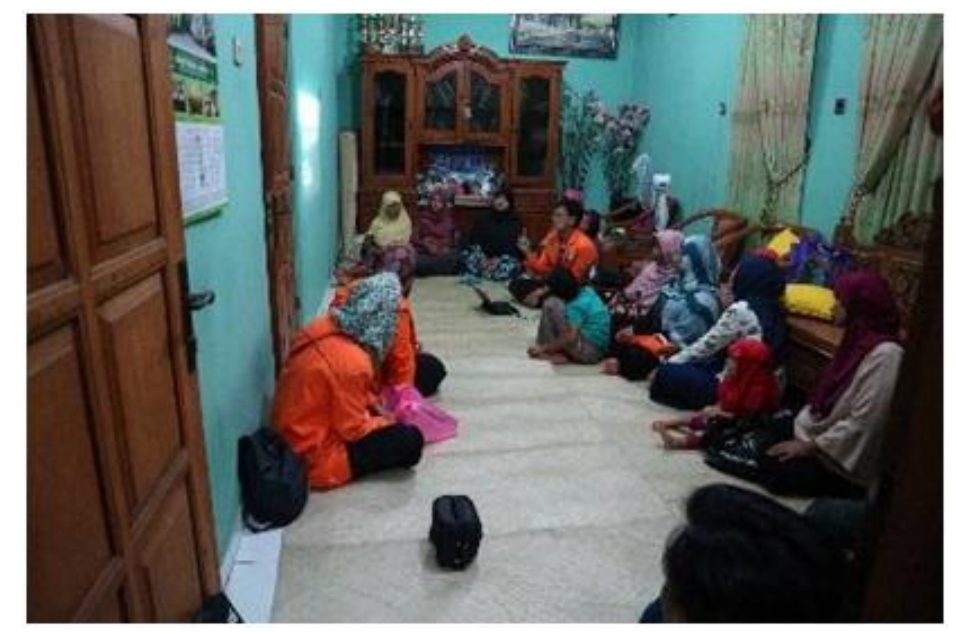

Gambar 1. Pelaksanaan penyuluhan mengenai hipertensi pada ibu-ibu 


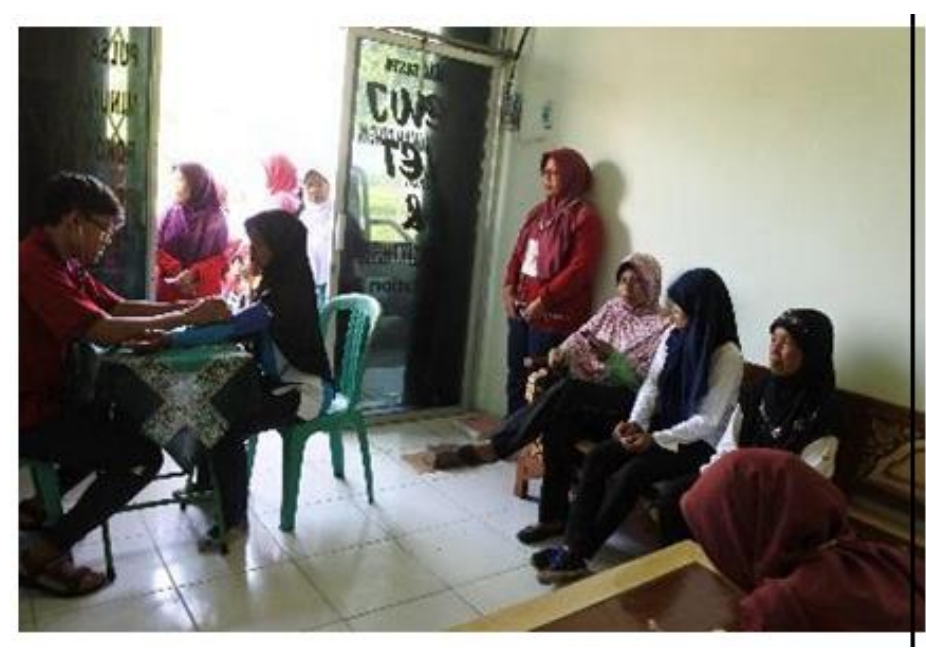

Gambar 2. Pemeriksaan tekanan darah dalam pendeteksian hipertensi pada ibu-ibu Bantar Kulon dan Bantar Wetan

Promosi kesehatan yang dilakukan adalah dengan metode penyuluhan tentang hipertensi dan faktor risiko terjadinya hipertensi. Penyuluhan ini bertujuan memberikan pengetahuan mengenai hipertensi kepada masyarakat supaya masyarakat dapat melakukan upaya pencegahan penyakit hipertensi. Informasi yang didapatkan dari penyuluhan dapat memberikan pengaruh jangka pendek sehingga dapat menghasilkan perubahan atau peningkatan pengetahuan (Widianingrum and Dewi, 2013). Semakin meningkatnya pengetahuan pasien tentang hipertensi akan mendorong seseorang untuk berperilaku yang lebih baik dalam mengontrol hipertensi sehingga tekanan darahnya tetap terkendali, pengetahuan pasien mengenai hipertensi juga berpengaruh pada kepatuhan pasien dalam melakukan pengobatan. Seiring dengan meningkatnya pengetahuan tentang hipertensi maka dapat melakukan penatalaksanaan penyakitnya sehingga pasien menjadi lebih baik (Wulansari, Ichsan and Usdiana, 2013). Pengetahuan yang baik tentang hipertensi dapat mempengaruhi perilaku masyarakat dalam mencegah hipertensi (Limbong, Rumayar and Kandou, 2016).

Berdasarkan penelitian Muthia dkk., didapatkan bahwa terdapat perbedaan yang bermakna antara tingkat pengetahuan akhir dengan tingkat pengetahuan awal pada responden yang mendapat penyuluhan kesehatan. Penyuluhan kesehatan merupakan suatu kegiatan yang dapat mempengaruhi perubahan perilaku responden, salah satunya perubahan pengetahuan. Dengan diberikannya penyuluhan maka responden mendapat pembelajaran yang menghasilkan suatu perubahan dari yang semula belum mengetahui menjadi mengetahui dan yang dahulu belum memahami menjadi memahami (Muthia, Fitriangga and R.S.A, 2016). 
Penyuluhan dengan metode ceramah lebih efektif dibandingkan dengan demonstrasi terhadap peningkatan pengetahuan kesehatan. Hal tersebut dikarenakan metode ceramah dinilai lebih efektif digunakan pada pendengar yang lebih dari sepuluh orang namun sering menimbulkan kebosanan jika materi yang disampaikan kurang menarik dan terlalu panjang (Bany, Sunnati and Darman, 2014).

\section{SIMPULAN}

Kegiatan pengabdian kepada masyarakat di Dusun Bantar Kulon Banguncipto Sentolo dapat berjalan dengan baik dan lancar. Peserta sangat aktif, antusias, dan dapat bekerjasama dengan baik. Diharapkan dengan kegiatan pengabdian kepada masyarakat ini masyarakat memiliki pengetahuan yang baik mengenai hipertensi.

\section{DAFTAR PUSTAKA}

Bany, Z. U., Sunnati and Darman, W. (2014) 'Perbandingan Efektivitas Penyuluhan Metode Ceramah dan Metode Demonstrasi Terhadap Pengetahuan Kesehatan Gigi dan Mulut Siswa SD', Cakradonya Dent J, 6(1), pp. 619-677.

Dinas Kesehatan Kabupaten Kulon Progo (2015) Profil Kesehatan Kabulaten Kulon Progo Tahun 2015. Yogyakarta: Dinas Kesehatan Kulon Progo.

Dirhan (2012) 'Hubungan Pengetahuan, Sikap Dan Ketaatan Berobat Dengan Derajat Sistole Dan Diastole Pasien Hipertensi', Jurnal Ilmiah Farmasi, 9(1). Available at: https://media.neliti.com/media/publications/97684-ID-hubungan-pengetahuan-sikapdan-ketaatan.pdf.

Fitria, W. D. and Candrasari, A. (2010) 'Peningkatan Pengetahuan Tentang Hipertensi pada Lansia di Posyandu Lansia Dukuh Gantungan Desa Makamhaji Kartasura Sukoharjo', Warta, 13, pp. 28-36.

Kementerian Kesehatan Republik Indonesia (2017) Hipertensi. Jakarta: Pusat Data dan Informasi Kementerian Kesehatan Republik Indonesia. doi: 10.1177/109019817400200403.

Kementerian Kesehatan Republik Indonesia and Kementerian Kesehatan Republik Indonesia (2017) Sebagian Besar Penderita Hipertensi Tidak Menyadarinya. Available at: http://www.depkes.go.id/pdf.php?id=17051800002.

Limbong, V., Rumayar, A. and Kandou, G. (2016) 'Hubungan Pengetahuan dan Sikap Dengan Kejadian Hipertensi di Wilayah Kerja Puskesmas Tateli Kabupaten Minahasa', Jurnal KESMAS, 7(4).

Mardhiah, A., Abdullah, A. and Hermansyah (2013) 'Pendidikan Kesehatan Dalam Peningkatan Pengetahuan, Sikap Dan Keterampilan Keluarga Dengan Hipertensi Pilot Study', Jurnal Ilmu Keperawatan, pp. 111-121.

Muthia, F., Fitriangga, A. and R.S.A, S. N. Y. (2016) 'Perbedaan Efektifitas Penyuluhan Kesehatan menggunakan Metode Ceramah dan Media Audiovisual (Film) terhadap Pengetahuan Santri Madrasah Aliyah Pesantren Khulafaur Rasyidin tentang TB Paru Tahun 2015', Jurnal Cerebellum, 2(4), pp. 646-656. Available at: http://jurnal.untan.ac.id/index.php/jfk/article/viewFile/23546/18499.

Purwati, R. D., Bidjuni, H. and Babakal, A. (2014) 'Pengaruh Penyuluhan Kesehatan 
Terhadap Pengetahuan Perilaku Klien Hipertensi di Puskesmas Bahu Manado', Journal Keperawatan, 2(2), pp. 1-8.

Widianingrum, R. and Dewi, H. (2013) 'Efektifitas Penyuluhan Tentang Hipertensi pada Masyarakat Rentang Usia 45-60 Tahun Dibandingkan dengan Masyarakat Rentang Usia 61-75 Tahun', Jurnal Kedokteran Muhammadiyah, 1(2), pp. 86-92.

Wulansari, J., Ichsan, B. and Usdiana, D. (2013) 'Hubungan Pengetahuan Tentang Hipertesi Dengan Pengendaalian Tekanan Darah Pada Pasien Hipertensi Di Poliklinik Penyakit Dalam RSUD DR. MOEWARDI SURAKARTA', Biomedika, 5(1), pp. 17-22.

\section{UCAPAN TERIMAKASIH}

Terima kasih diucapkan kepada:

1. Universitas Ahmad Dahlan sebagai penyumbang dana sehingga kegiatan pengabdian kepada masyarakat ini dapat berjalan dengan lancar dan baik.

2. Pemerintah Desa Banguncipto Sentolo Kulon Progo yang terlah memberikan dukungan dan bantuan selama proses pelaksanaan kegiatan pengabdian kepada masyarakat.

3. Dusun Bantar Kulon dan ibu-ibu dasawisma yang telah mendukung dan aktif berperan dalam pelaksanaan program pengabdian kepada masyarakat. 